\title{
Pool boiling heat transfer for surfaces with microchannels of variable depth
}

\author{
Robert Pastuszko ${ }^{1 *}$, Milena Bedla-Pawlusek $^{2}$ and Robert Kaniowski ${ }^{1}$ \\ ${ }^{1}$ Kielce University of Technology, Faculty of Mechatronics and Mechanical Engineering, al. 1000-lecia Państwa Polskiego 7 , \\ PL-25-314 Kielce, Poland \\ ${ }^{2}$ Holy Cross Cancer Center, Technical Department, Artwińskiego Street 3, PL-25-734 Kielce
}

\begin{abstract}
Experimental investigations of pool boiling heat transfer on microchannels of variable depth were conducted. The experiments were carried out for water and ethanol at atmospheric pressure. Microchannels of variable depth from 0.2 to $2.8 \mathrm{~mm}$ and width $0.5 \mathrm{~mm}$ were uniformly spaced on base surface with pitch of $1 \mathrm{~mm}$. The comparison of heat transfer coefficients for surfaces with variable and constant depth of microchannels was made. At the low and medium heat fluxes structures with constant microchannel depth showed the best boiling heat transfer performance. EX-FH20 (Casio) camera was used to record the images of the entire surface of the specimen. The bubble growth mechanism on the enhanced surface was different from that of plain surface. Visualization investigations were aimed at identifying nucleation sites and determining the bubble growth cycle. Vapor bubbles generate in microchannel spaces, from where they move towards the fin tips, then grow and depart.
\end{abstract}

\section{Introduction}

The paper deals with experimental investigations of boiling heat transfer on a system of parallel horizontal channels. This structures can be applied for cooling miniature integrated devices, such as microprocessors, by a direct or indirect method (as a thermosyphon or tube evaporator), substituting forced convection (traditional fan). An overview of the surfaces with microchannels and the heat transfer coefficients obtained are presented in Table 1.

Table 1. Types of open microchannels for pool boiling enhanced heat transfer

\begin{tabular}{|c|c|c|c|}
\hline Reference & Configuration & Liquid & The highest HTC \\
\hline $\begin{array}{l}\text { Cooke and } \\
\text { Kandlikar [1] }\end{array}$ & $\begin{array}{l}\text { silicon micro-channels } 40-200 \mu \mathrm{m} \text { wide and } 180 \\
-275 \mu \mathrm{m} \text { deep, etched in silicon plates }\end{array}$ & water & $73 \mathrm{~kW} / \mathrm{m}^{2} \mathrm{~K}$ \\
\hline $\begin{array}{l}\text { Cooke and } \\
\text { Kandlikar [2] }\end{array}$ & $\begin{array}{l}\text { copper micro-channels } 0.2-0.4 \mathrm{~mm} \text { wide and } \\
0.100-0.400 \mathrm{~mm} \text { deep }\end{array}$ & water & $\begin{array}{l}269 \mathrm{~kW} / \mathrm{m}^{2} \mathrm{~K} \text { (channel width } 0.375 \\
\mathrm{~mm} \text {, depth } 0.4 \mathrm{~mm} \text { ) }\end{array}$ \\
\hline $\begin{array}{l}\text { Jaikumar and } \\
\text { Kandlikar [3] }\end{array}$ & $\begin{array}{l}\text { microchannels } 300 \mu \mathrm{m}, 500 \mu \mathrm{m} \text { and } 762 \mu \mathrm{m} \text { wide, } \\
\text { three coating configurations: sintered-throughout, } \\
\text { sintered-fin-tops, sintered-channels. }\end{array}$ & water & $\begin{array}{l}2900 \mathrm{~kW} / \mathrm{m}^{2} \mathrm{~K}, \text { relative to the } \\
\text { structured } 10 \times 10 \mathrm{~mm}^{2} \text { surface }\end{array}$ \\
\hline $\begin{array}{l}\text { Patil and } \\
\text { Kandlikar [4] }\end{array}$ & $\begin{array}{l}\text { microchannels ( } 300-762 \mu \mathrm{m} \text { wide, } 200-400 \mu \mathrm{m} \\
\text { deep) with micro-porous coatings on the fin tops }\end{array}$ & water & $\begin{array}{l}995 \mathrm{~kW} / \mathrm{m}^{2} \mathrm{~K} \text { for the } 762 \mu \mathrm{m} \text { wide } \\
\text { channel }\end{array}$ \\
\hline $\begin{array}{l}\text { Kalani and } \\
\text { Kandlikar [5] }\end{array}$ & $\begin{array}{l}\text { copper microchannels } 245-470 \mu \mathrm{m} \text { deep and } 194 \\
-406 \mu \mathrm{m} \text { wide }\end{array}$ & ethanol & $\begin{array}{l}72 \mathrm{~kW} / \mathrm{m}^{2} \mathrm{~K} \text { for } 0.207 \mathrm{~mm} \text { wide } \\
\text { and } 0.456 \mathrm{~mm} \text { deep channel }\end{array}$ \\
\hline $\begin{array}{l}\text { Jaikumar and } \\
\text { Kandlikar [6] }\end{array}$ & $\begin{array}{l}\text { copper } 762 \mu \mathrm{m} \text { wide and } 400 \mu \mathrm{m} \text { deep open } \\
\text { microchannel; coating configurations as in [4] }\end{array}$ & water & $565 \mathrm{~kW} / \mathrm{m}^{2} \mathrm{~K}$ \\
\hline $\begin{array}{l}\text { Jaikumar and } \\
\text { Kandlikar [7] }\end{array}$ & $\begin{array}{l}\text { copper open microchannels with porous fin tops } \\
\text { on (widths: } 300-762 \mu \mathrm{m} \text {, depths: } 200-400 \mu \mathrm{m} \text { ) }\end{array}$ & FC-87 & $\begin{array}{l}20 \mathrm{~kW} / \mathrm{m}^{2} \mathrm{~K} \text { for the channel with } \\
\text { the width and depth of } 400 \mu \mathrm{m}\end{array}$ \\
\hline $\begin{array}{l}\text { Gheitaghy et al. } \\
\text { [8] }\end{array}$ & $\begin{array}{l}\text { copper surface on } 45^{\circ} \text { inclined microchannels } \\
\text { (widths: } 0.5-0.7 \mathrm{~mm} \text {, depths: } 0.5-1 \mathrm{~mm} \text { ) }\end{array}$ & water & $\begin{array}{l}\text { about } 120 \mathrm{~kW} / \mathrm{m}^{2} \mathrm{~K} \text { for the channel } \\
\text { width } 0.5 \mathrm{~mm} \text { and depth } 1.4 \mathrm{~mm}\end{array}$ \\
\hline $\begin{array}{l}\text { Kaniowski et al. } \\
\text { [9] }\end{array}$ & microchannels $0.2-0.4 \mathrm{~mm}$ deep, $0.3 \mathrm{~mm}$ wide & $\begin{array}{l}\text { water } \\
\text { Novec- } \\
649\end{array}$ & $\begin{array}{l}\text { about } 64 \mathrm{~kW} / \mathrm{m}^{2} \mathrm{~K} \text { (water) and } 8 \\
\mathrm{~kW} / \mathrm{m}^{2} \mathrm{~K} \text { (Novec-649) }\end{array}$ \\
\hline $\begin{array}{l}\text { Kaniowski and } \\
\text { Pastuszko [10] }\end{array}$ & $\begin{array}{l}\text { copper microchannels } 0.3 \mathrm{~mm} \text { wide, } 0.2-0.5 \mathrm{~mm} \\
\text { deep }\end{array}$ & $\begin{array}{l}\text { water } \\
\text { ethanol } \\
\text { FC-72 }\end{array}$ & $\begin{array}{l}63 \mathrm{~kW} / \mathrm{m}^{2} \mathrm{~K} \text { (water), } 20 \mathrm{~kW} / \mathrm{m}^{2} \mathrm{~K} \\
\text { (ethanol) }\end{array}$ \\
\hline
\end{tabular}

*Corresponding author: tmprp@tu.kielce.pl 


\begin{tabular}{|c|c|c|c|}
\hline $\begin{array}{l}\text { Kaniowski and } \\
\text { Pastuszko [11] }\end{array}$ & $\begin{array}{l}\text { copper microchannels } 0.3 \mathrm{~mm} \text { wide, } 0.2-0.5 \mathrm{~mm} \\
\text { deep }\end{array}$ & $\begin{array}{l}\text { ethanol } \\
\text { FC-72 }\end{array}$ & $\begin{array}{l}\text { exceeded } 20 \mathrm{~kW} / \mathrm{m}^{2} \mathrm{~K} \text { for ethanol } \\
\text { and } 10 \mathrm{~kW} / \mathrm{m}^{2} \mathrm{~K} \text { for FC- } 72\end{array}$ \\
\hline $\begin{array}{l}\text { Kalani } \quad \text { and } \\
\text { Kandlikar [12] }\end{array}$ & $\begin{array}{l}\text { copper open microchannels (widths: } 194-406 \\
\mu \mathrm{m} \text {, depths: } 245-470 \mu \mathrm{m}), 16.7-101.3 \mathrm{kPa}\end{array}$ & ethanol & $\begin{array}{l}\text { about } 65 \mathrm{~kW} / \mathrm{m}^{2} \mathrm{~K} \text { for the channel } \\
\text { width } 0.2 \mathrm{~mm} \text { and depth } 0.456 \mathrm{~mm} \\
\text { (at } 101.3 \mathrm{kPa} \text { ) }\end{array}$ \\
\hline $\begin{array}{l}\text { Rahman and } \\
\text { McCarthy [13] }\end{array}$ & $\begin{array}{l}\text { copper microchannel (characteristic lengths of } \\
300 \mu \mathrm{m} \text { to } 3 \mathrm{~mm} \text { ) with nanostructured coatings } \\
\text { (characteristic lengths of } 50 \mathrm{~nm} \text { to } 50 \mu \mathrm{m} \text { ) }\end{array}$ & water & $461 \mathrm{~kW} / \mathrm{m}^{2} \mathrm{~K}$ \\
\hline Kwak et al. [14] & $\begin{array}{l}\text { copper microchannel with } \mathrm{SiO}_{2} \text { layer (widths: } 30 \\
\mu \mathrm{m} \text {, depths: } 10-100 \mu \mathrm{m})\end{array}$ & water & $\begin{array}{l}\text { about } 60 \mathrm{~kW} / \mathrm{m}^{2} \mathrm{~K} \text { for the channel } \\
\text { width } 30 \mu \mathrm{m} \text {, depths } 100 \mu \mathrm{m}\end{array}$ \\
\hline $\begin{array}{l}\text { Walunj and } \\
\text { Sathyabhama } \\
\text { [15] }\end{array}$ & $\begin{array}{l}\text { rectangular, parabolic and stepped microchannels } \\
\text { on } 10 \text {-mm diameter copper rod; channel widths: } \\
250-800 \mu \mathrm{m} \text {; depth: } 500 \mu \mathrm{m} \text {. }\end{array}$ & water & about $16 \mathrm{~kW} / \mathrm{m}^{2} \mathrm{~K}$ \\
\hline
\end{tabular}

The objective of this article is comparison of surfaces with variable and constant depth microchannels with respect to boiling heat transfer enhancement, taking into account microchannels of $0.4-0.5 \mathrm{~mm}$ in wide.

\section{Experimental setup}

The diagram of the measurement stand for the determination of boiling curves is presented in Figure 1.

The main stand module (Fig. 2) consists of a vessel with four flat glass walls (2), filled with working fluid, and placed over the investigated sample (3). The sample was soldered to a $170 \mathrm{~mm}$ long cylindrical copper bar of $45 \mathrm{~mm}$ diameter. The cylinder diameter corresponded to the diagonal of the sample base. A $1000 \mathrm{~W}$ electric cartridge heater of $19 \mathrm{~mm}$ diameter and $130 \mathrm{~mm}$ long was installed into the bar. Before assembly the heater was coated with a special thermal paste to eliminate air spaces and decrease thermal resistance between the heater and cylinder material.

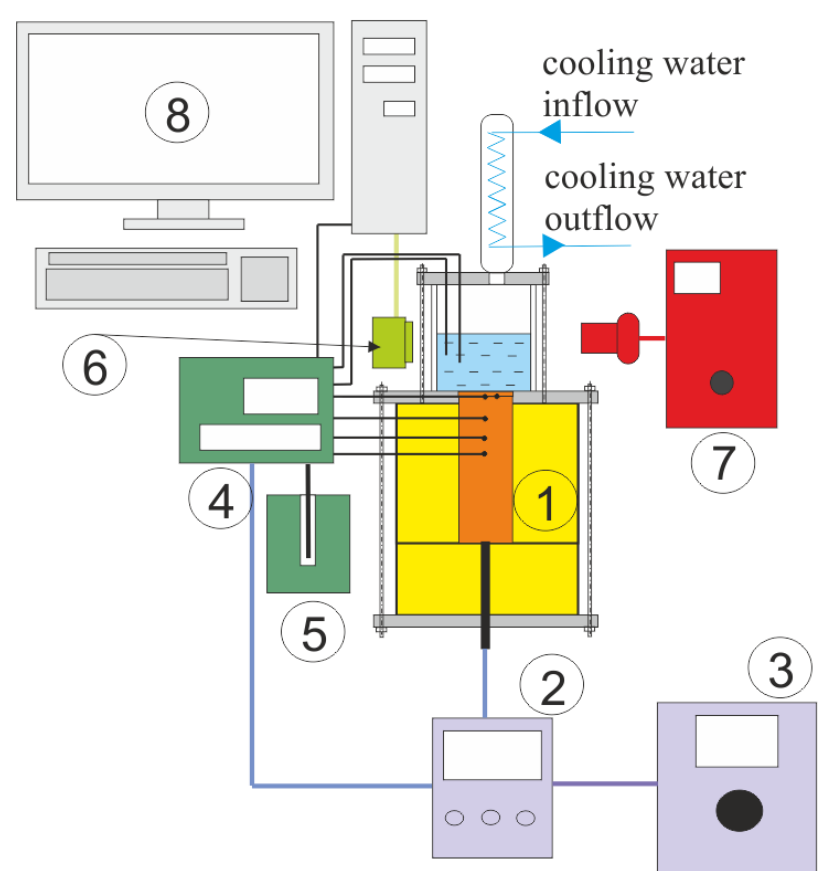

Fig. 1. Measurement system: 1 - main module, 2 - wattmeter, 3 - autotransformer, 4 - data logger , 5 -dry-well calibrator, 6 - high speed camera, 7 - lights, 8 - PC.
Type $K(\mathrm{NiCr}-\mathrm{NiAl})$ sheathed thermocouples of 0.5 $\mathrm{mm}$ in diameter were used for the measurements. They were placed as follows:

- in the liquid - saturation temperature measurement $(T 1, T 2)$,

- under the sample - extrapolated to fin base temperature $(T 3, T 4)$,

- in the bar at 5, 10, 20 and $35 \mathrm{~mm}$ depth (Fig .3) temperature gradient determination $(T 5, T 6, T 7$, T8).

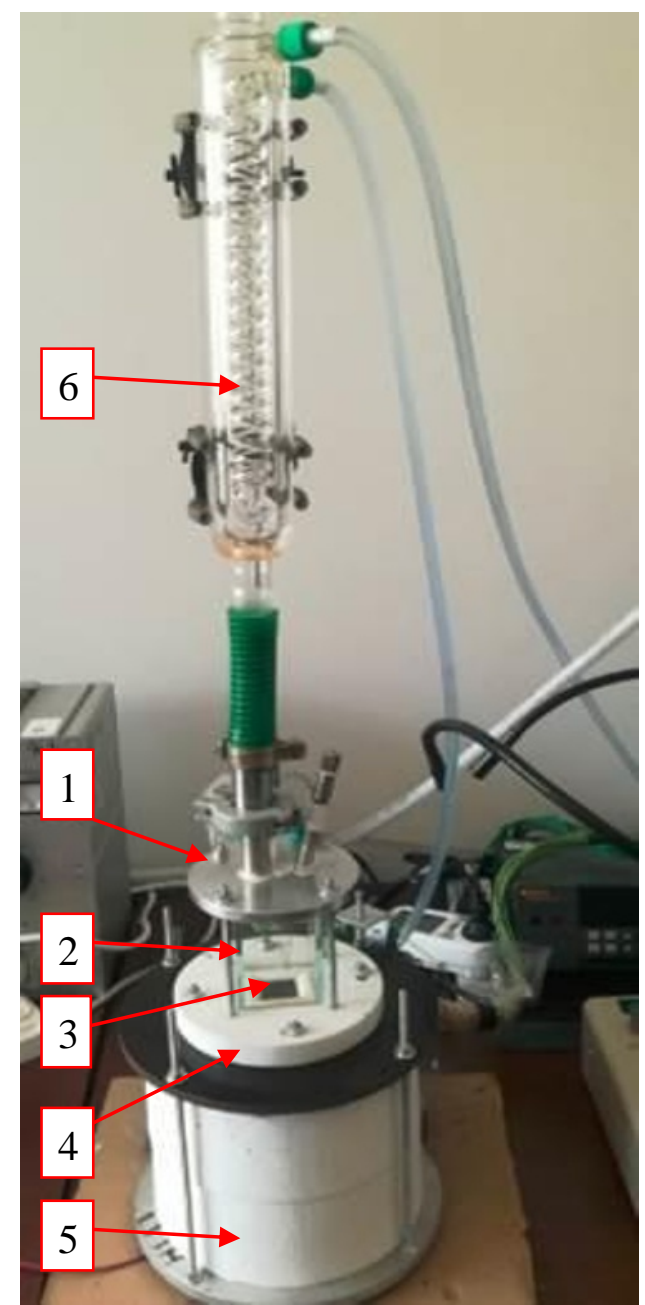

Fig. 2. Main module; 1 - top flange, 2 - glass vessel, 3 sample, 4 - teflon annular flange, 5 - insulation, 6 - condenser. 


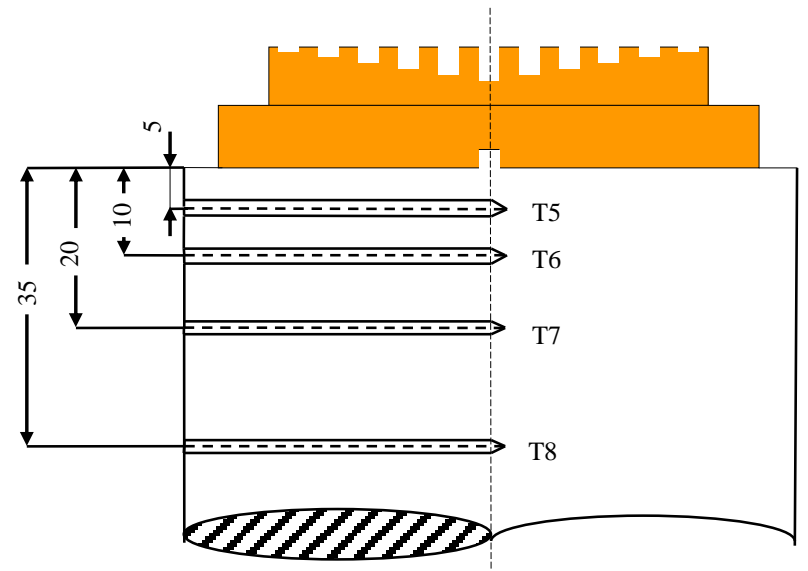

Fig. 3. Arrangement of thermocouples.

The heat flux was determined on the basis of the temperature gradient in the upper part of the heating cylinder, assuming one-dimensional heat conduction

$$
q=\frac{\lambda_{C u} \Delta T_{T 5-T 8}}{l_{T 5-T 8}}
$$

Temperature superheat $(\Delta T)$ was related to micro-fin base. Due to the shift of the temperature measurement point, the superheat was calculated with the following dependence

$$
\Delta T=\frac{T_{T 3}+T_{T 4}}{2}-\frac{q l_{T 3, b s}}{\lambda_{C u}}-T_{\text {sat }}
$$

$l_{T 3, b s}$ - means the distance between the microchannel top and thermocouples under the sample $(T 3, T 4)$. The estimated uncertainties were as follows:

- low heat flux $\left(2 \mathrm{~kW} / \mathrm{m}^{2}\right)$ : heat flux $\pm 35 \%$, heat transfer coefficient $\pm 40 \%$,

- high heat flux $\left(550 \mathrm{~kW} / \mathrm{m}^{2}\right)$ : heat flux $\pm 1.2 \%$, heat transfer coefficient $\pm 2.2 \%$.

The method of Kline and McClintock was used to determine uncertainty. The quoted heat fluxes referred to the fin bases. The heat transfer coefficient was expressed as:

$$
\alpha=\frac{q}{\Delta T}
$$

\section{Test surfaces}

Original studies were conducted in order to plot boiling curves and perform visualisations on two types of structures (Figs. 4 and 5):

- with open microchannels of constant depth - MC

- with open microchannels of variable depth - MCV.

The samples with microchannels were made of copper and had parallel grooves with a constant pitch, made with an end mill (CNC machining process). The test section with a $27 \times 27 \mathrm{~mm}^{2}$ boiling region consisted of a $32 \times 32 \mathrm{~mm}^{2}$ base square copper sample.

Table 2 compiles the surface codes and specifications according to Figs 4 and 5.

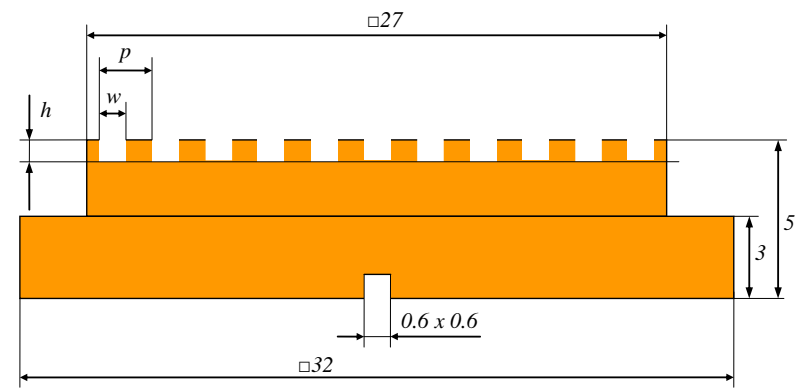

a)

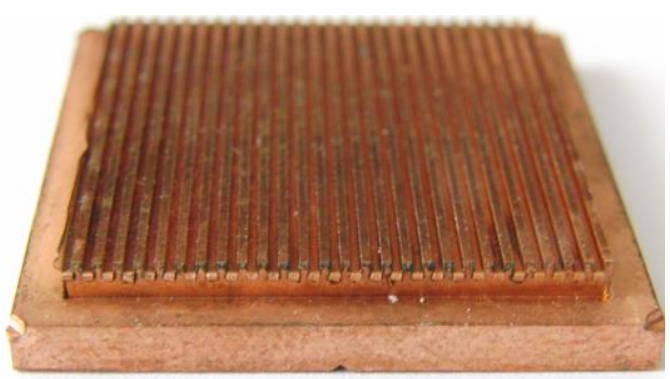

b)

Fig. 4. a) Dimension symbols of the surface MC, b) view of the sample MC.

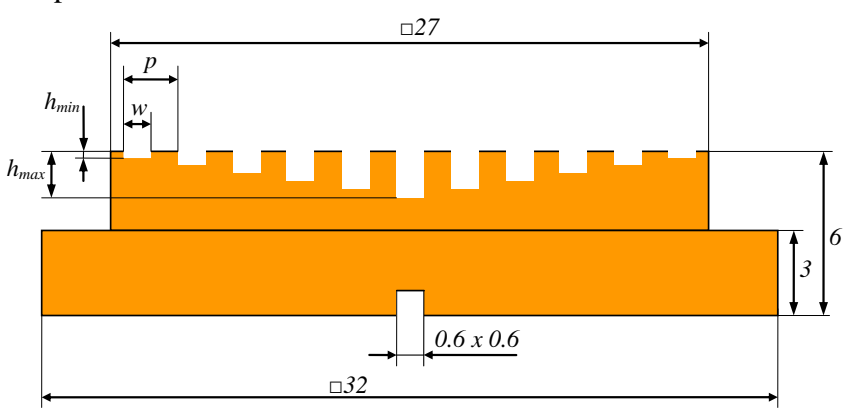

a)

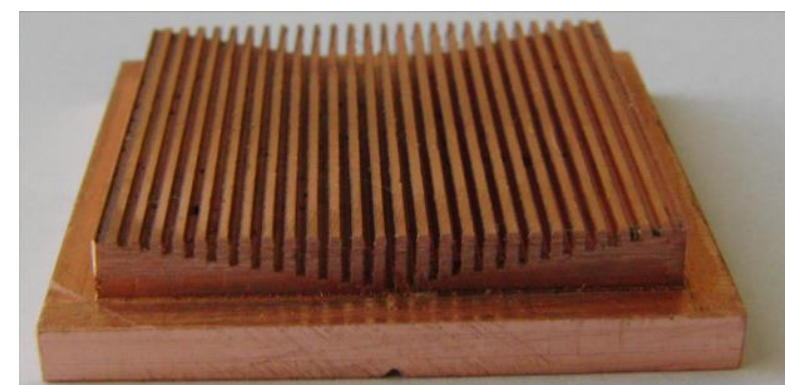

b)

Fig. 5. a) Dimension symbols of the surface MCV, b) view of the sample MCV.

Table 2. MC/MCV surface codes and specifications.

\begin{tabular}{|c|c|c|c|c|c|}
\hline Sample code & $\begin{array}{l}w \\
\mathrm{~mm}\end{array}$ & $\begin{array}{l}h_{\min } \\
\mathrm{mm}\end{array}$ & $\begin{array}{l}h_{\max } \\
\mathrm{mm}\end{array}$ & $\begin{array}{l}\Delta h \\
\mathrm{~mm}\end{array}$ & $\begin{array}{l}p \\
\mathrm{~mm}\end{array}$ \\
\hline MC-0.4-0.5-0.8 & 0.4 & 0.5 & 0.5 & 0 & 0.8 \\
\hline MCV-0.5-0.2_2.8-1 & 0.5 & 0.2 & 2.8 & 0.2 & 1.0 \\
\hline
\end{tabular}




\section{Results}

Two types of surfaces (MC and MCV) were examined to study the influence of the kind of extended surface on nucleate boiling heat transfer performance for two different liquids (water, ethanol).

The effect of the microchannel depth and width for water is shown in Fig. 6. The best results, with low and medium heat fluxes $\left(q<350 \mathrm{~kW} / \mathrm{m}^{2}\right)$ were obtained for microchannels with variable depth (MCV). For higher heat fluxes microchannels with constant depth (MC) shows about $10 \%$ higher heat transfer coefficients than surface MCV. Boiling heat transfer enhancement for MCV related to plain surface $\left(\alpha / \alpha_{\mathrm{ps}}\right)$ is about 2 at heat fluxes $100-350 \mathrm{~kW} / \mathrm{m}^{2}$.

With ethanol boiling, the performance of microchannels has proved especially good for the MC surface (Fig. 7). Boiling heat transfer enhancement related to plain surface $\left(\alpha / \alpha_{\mathrm{ps}}\right)$ is $2-1.5$ in the range $q=$ $100-300 \mathrm{~kW} / \mathrm{m}^{2}$. Compared with MC surface, MCV surface gave lower heat transfer coefficients especially for higher heat fluxes $\left(q>300 \mathrm{~kW} / \mathrm{m}^{2}\right)$.

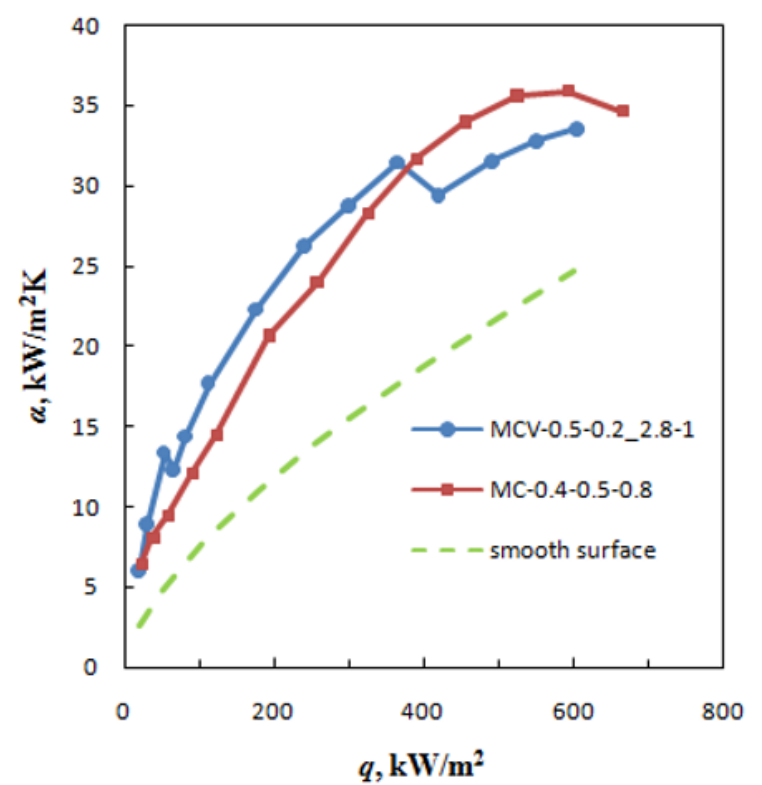

Fig. 6. Boiling curves for water, heat transfer coefficient vs. heat flux.

The mechanism of bubble nucleation, growing and departing is shown in Figs 8 and 9. Vapor bubble generated in microchannel spaces between neighboring microfins in the corner at the microchannel base. It grew and moved towards the microfin tip. The second stage of growth was observed when the bubble adhered to the top of the microfin. Increasing volume of the bubble increased buoyancy force. The growing bubble departed from the microfin top.

For microchannels of variable depth predicted boiling mechanism may be related to macroconvection with separate liquid-vapor pathways as well as with sustion-evaporation mode.

Figure 10 shows predicted boiling mechanism for microchannels with changing channels' depth. Small

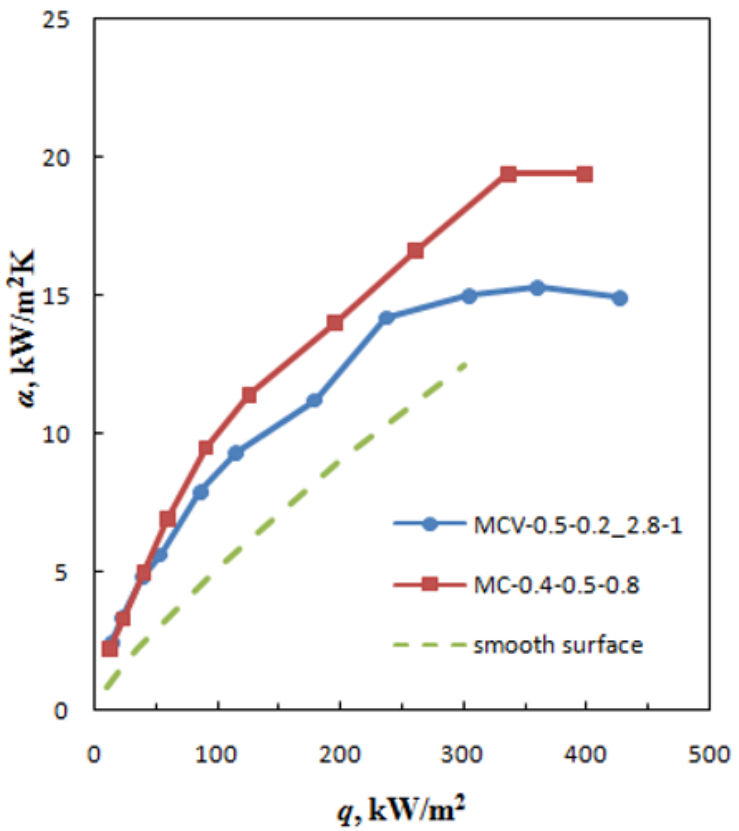

Fig. 7. Boiling curves for ethanol, heat transfer coefficient vs. heat flux.

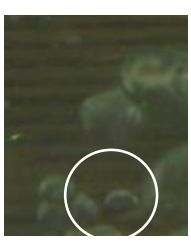

a)

Fig. 8. Visualization observations of pool boiling of water on the microchannel surface MC-0.5-0.2_2.8-1, $q=30 \mathrm{~kW} / \mathrm{m}^{2}$, a) $d=0.6 \mathrm{~mm}, \mathrm{~b}) d=0.9 \mathrm{~mm}, \mathrm{c}) d=1.4 \mathrm{~mm}, \mathrm{~d}) d=2.1 \mathrm{imm}$.

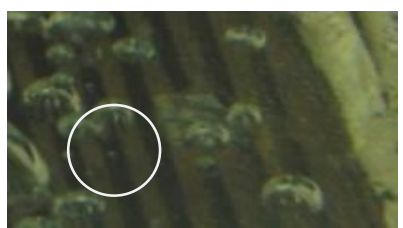

a)
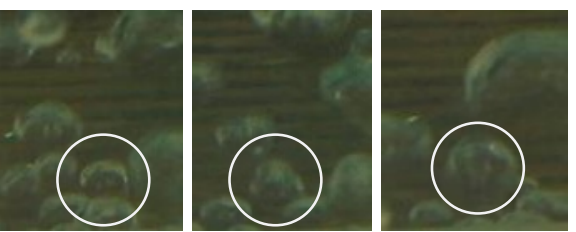

d)
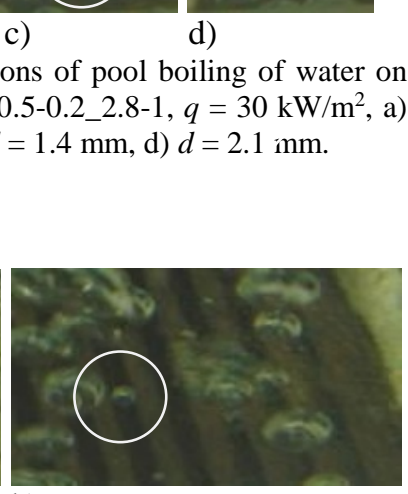

b)

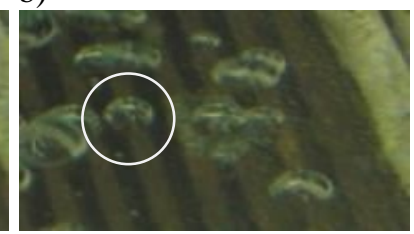

d)

c)

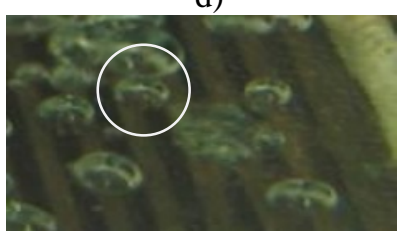

e)

Fig. 9. Visualization observations of pool boiling of ethanol on the microchannel surface MCV-0.5-0.2_2.8-1, $q=30 \mathrm{~kW} / \mathrm{m}^{2}$, a) $d=0.25 \mathrm{~mm}, \mathrm{~b}) d=0.5 \mathrm{~mm}$, c) $d=0.75 \mathrm{~mm}, \mathrm{~d}$ ) $d=0.90$ $\mathrm{mm}$, e) $d=1.20 \mathrm{~mm}$. 
depth channels will contribute to the onset of nucleate boiling (ONB) at low superheating, but at medium heat flux heat transfer coefficient decreases after dry-out heat flux (DHF) is reached. Microchannels with greater depth improve the pool boiling performance at higher heat flux - they do not only provide an aditional surface for boiling heat transfer and nucleation, but they can prevent large bubbles from coalescing into a vapor blanket. This kind of vapor layer could cover the whole MC surface and ultimately dry out. Deep microchannels can eliminate this phenomenon, so that the critical heat flux (CHF) will have higher values.

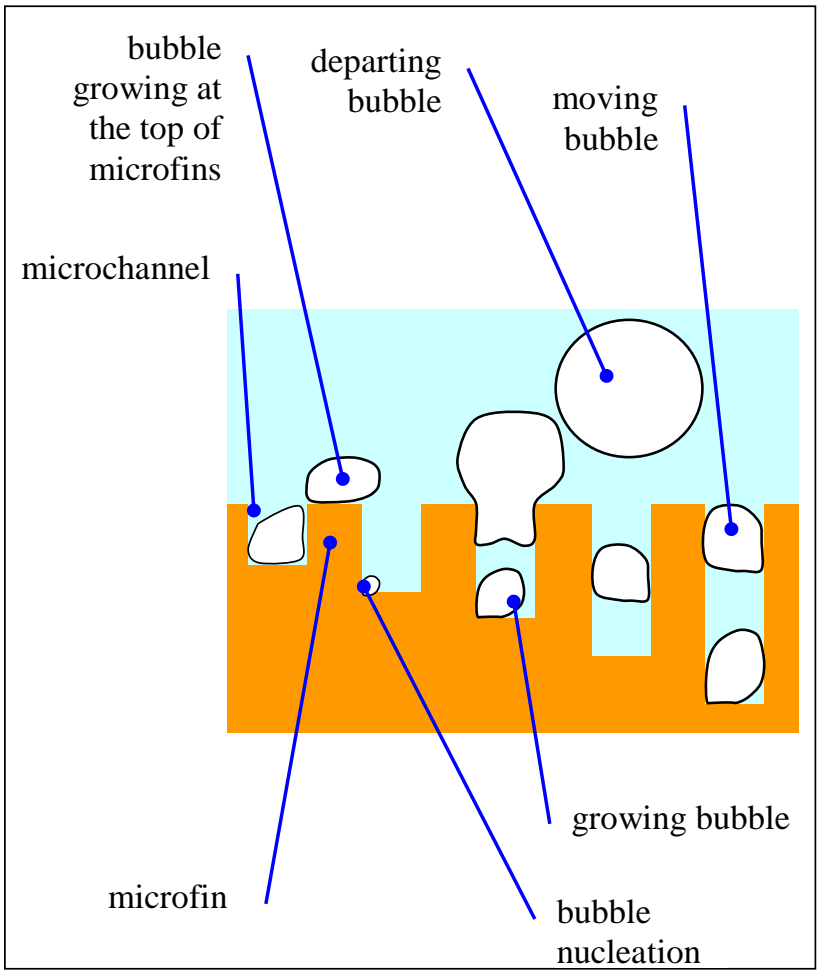

Fig. 10. Mixed boiling mode in microchannels of variable depth.

\section{Conclusion}

The following conclusions can be drawn from the experiments:

- When boiling water on microchannels with constant (MC) and variable depth (MCV), similar heat transfer coefficients (HTC) were obtained. During the boiling of ethanol, higher HTC values occurred at the highest heat fluxes.

- Visualization studies allowed the recognition of a two-stage bubble growing mechanism: initially at the bottom of the microchannel, and later at the top of the microfins that limit the microchannel.

- More exact conclusions can be drawn after testing a larger number of samples with MC and MCV surfaces in the range of $0.2 \mathrm{~mm}$ and $0.6 \mathrm{~mm} \mathrm{~mm}$.

\section{Nomenclature}

CHF - critical heat flux,

d - diameter, $\mathrm{m}$,

h - depth, m,

HTC - heat transfer coefficient,

$l$ - distance between thermocouples, $\mathrm{m}$,

MC - microchannel,

MCV - microchannel with variable depth,

$p \quad-$ pitch, m,

$q \quad$ - heat flux, $\mathrm{kW} / \mathrm{m}^{2}$,

$T$ - temperature, $\mathrm{K}$,

w $\quad$ - width, m,

\section{Greek symbols}

$\alpha \quad-$ heat transfer coefficient, $\mathrm{W} /\left(\mathrm{m}^{2} \mathrm{~K}\right)$,

$\lambda-$ thermal conductivity, $\mathrm{W} /(\mathrm{mK})$,

$\Delta h$ - change of depth, $\mathrm{m}$,

$\Delta T$ - difference of temperature, $\mathrm{K}$,

\section{Subscripts}

$\begin{array}{ll}b s & \text { - base, } \\ C u & \text { - copper, } \\ p s & \text { - plain surface, } \\ \text { sat } & \text { - saturation, }\end{array}$

\section{References}

1. D. Cooke, S. G. Kandlikar, J. Heat Transfer 133 (2011)

2. D. Cooke, S. G. Kandlikar, Int. J. Heat and Mass Transfer 55 (2012)

3. A. Jaikumar, S. G. Kandlikar, Int. J. Heat and Mass Transfer 95 (2016)

4. Ch. M. Patil, S. G. Kandlikar, Int. J. Heat and Mass Transfer 79 (2014)

5. A. Kalani, S.G. Kandlikar, proc. ASME 10th Int. Conf. Nanochannels, Microchannels and Minichannels, Rio Grande, Puerto Rico (2012)

6. A. Jaikumar, S. Kandlikar, Int. J. Heat and Mass Transfer 88 (2015)

7. A. Jaikumar, S. Kandlikar, App. Thermal Engineering 91 (2015)

8. A.M. Gheitaghy, A. Samimi, H. Saffari, App. Thermal Engineering 126 (2017)

9. R. Kaniowski, R. Pastuszko, Ł. Nowakowski, EPJ Web of Conferences 143, 02049 (2017)

10. R. Kaniowski, R. Pastuszko, EPJ Web of Conferences 180, 02042 (2018)

11. R. Kaniowski, R. Pastuszko, EPJ Web of Conferences 180, 02041 (2018)

12. A. Kalani, S.G. Kandlikar, J. Heat Transfer. 135 (2013)

13. M.M. Rahman, M. McCarthy, J. Heat Transfer 139 (2017)

14. H. J. Kwak, J. H. Kim, B. Myung, M. H. Kim, D. E. Kim, Int. J. of Thermal Sciences 125 (2018)

15. A. Walunj, A. Sathyabhama, Appl. Therm. Eng. 128 (2018) 